\title{
The Fractional Order PID Control of the Forced Air Heating System
}

\author{
Krzysztof Oprzędkiewicz, Maciej Podsiadło
}

AGH Akademia Górniczo-Hutnicza, Wydział Elektrotechniki, Automatyki, Informatyki I Inżynierii Biomedycznej, al. A. Mickiewicza 30, 30-059 Kraków

\begin{abstract}
The paper presents the implementation of the Fractional Order PID controller to control the temperature in the isothermal room applied in a pharmaceutical factory. The formula of the controller dedicated to transfer function model of the temperature is proposed, the stability analysis using the Matignon Theorem is also presented. Results of simulations show that the proposed controller is able to assure the better control quality than PID controller tuned with the use of auto-tuning function.
\end{abstract}

Keywords: Fractional Order PID controller, forced heating system, stability, ORA approximation

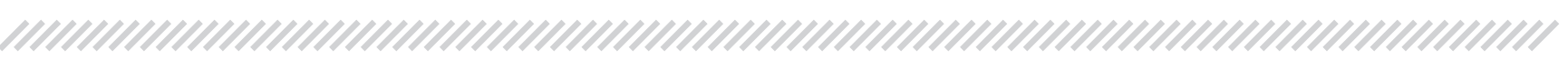

\section{Introduction}

The Fractional Order PID control (FOPID control) is the "classic" application of fractional order calculus in automation. Advantages of this idea are well known. A FOPID controller is able to assure better control quality and robustness than Integer Order (IO) PID due to use two additional parameters to its tune. FOPID controllers are considered by many Authors, for example: $[1,2,8,10,13]$. The recent state of the art is given in [8]. Tuning rules for FOPID controllers are given for example in $[3,7,12,14]$.

This paper is devoted to present the use of FOPID controller to temperature control in isothermal room, used for example in pharmaceutical factory. The job of the control system is to keep a constant, relatively high temperature inside the room. The main disturbation is variable outside temperature, varying dependently on season and weather.

The paper is organized as follows: at the beginning some elementary ideas from fractional calculus are recalled. Next the considered control plant and its integer order transfer function model are given. Furthermore the FOPID controller is proposed and stability analysis for selected order of the controller is presented. Results are by simulations illustrated.

\section{Preliminaries}

\subsection{Elementary ideas}

A presentation of elementary ideas is started with a definition of a fractional order, integro-differential operator $[2,4,5,11]$ :

Autor korespondujący:

Krzysztof Oprzędkiewicz, kop@agh.edu.pl

Artykuł recenzowany

nadesłany 22.01.2019 r., przyjęty do druku 14.03.2019 r.
Definition 1. (The elementary non integer order operator)

The fractional order, integro-differential operator is defined as follows:

$$
{ }_{a} D_{t}^{\alpha} f(t)= \begin{cases}\frac{d^{\alpha} f(t)}{d t^{\alpha}} & \alpha>0 \\ f(t) & \alpha=0 \\ \int_{a}^{t} f(\tau)(d \tau)^{\alpha} & \alpha<0\end{cases}
$$

where $a$ and $t$ denote time limits for operator calculation, $\alpha \in \mathbb{R}$ denotes the non-integer order of the operation.

Next the Gamma Euler function is recalled (see for example [5]):

Definition 2. (The Gamma function)

$$
\Gamma(x)=\int_{0}^{\infty} t^{x-1} e^{-t} d t
$$

Mittag-Leffler function is a non-integer order generalization of exponential function $e^{\lambda t}$ and it plays crucial role in solution of FO state equation. The one parameter Mittag-Leffler function is defined as follows:

Definition 3. (The one parameter Mittag-Leffler function)

$$
E_{\alpha}(x)=\sum_{k=0}^{\infty} \frac{x^{k}}{\Gamma(k \alpha+1)}
$$

The fractional-order, integro-differential operator is described by different definitions, given by Grünwald and Letnikov (GL definition), Riemann and Liouville (RL definition) and Caputo (C definition). In the further consideration only $\mathrm{C}$ definition is applied: 
Definition 4. (The Caputo definition of the FO operator)

$$
{ }_{0}^{C} D_{t}^{\alpha} f(t)=\frac{1}{\Gamma(N-\alpha)} \int_{0}^{\infty} \frac{f^{(N)}(\tau)}{(t-\tau)^{\alpha+1-N}} d \tau,
$$

where $N-1<\alpha<N$ denotes the fractional order of operation and $\Gamma(.$.$) is the complete Gamma function expressed by (2).$

For the $\mathrm{C}$ definition the Laplace transform is defined as follows:

Definition 5. (The Laplace transform for Caputo operator)

$$
\begin{aligned}
\mathcal{L}\left[{ }_{0}^{C} D_{t}^{\alpha} f(t)\right] & =s^{\alpha} F(s), \quad \alpha<0 \\
\mathcal{L}\left[{ }_{0}^{C} D_{t}^{\alpha} f(t)\right] & =s^{\alpha} F(s)-\sum_{k=0}^{n-1} s^{\alpha-k-1}{ }_{0} D_{t}^{k} f(0), \\
\alpha & >0, \quad n-1<\alpha \leq n \in N
\end{aligned}
$$

The use of $C$ definition (4) and (5) allows to define the fractional order transfer function, analogically to integer order case:

$$
G_{1}(s)=\frac{b_{M} s^{\beta_{M}}+\ldots+b_{1} s^{\beta_{1}}+b_{0}}{a_{N} s^{\alpha_{N}}+\ldots+a_{1} s^{\alpha_{1}}+a_{0}}
$$

where $\beta_{M} \ldots \beta_{1}$ and $\alpha_{N^{\ldots}} \alpha_{1}$ are fractional orders, $b_{M} \ldots b_{0}$ and $a_{N^{\prime}} a_{0}$ are coefficients. In the particular case the commensurate order system can be considered. This denotes that: $\beta_{m}=m \gamma, m=1$, $\ldots, M, \alpha_{N}=n \gamma, n=1, \ldots, N, M \leq N$. Consequently the transfer function (6) takes the following form:

$$
G_{1}(s)=\frac{b_{M}\left(s^{\gamma}\right)^{M}+\ldots+b_{1} s^{\gamma}+b_{0}}{a_{N}\left(s^{\gamma}\right)^{N}+\ldots+a_{1} s^{\gamma}+a_{0}}=\frac{L\left(s^{\gamma}\right)}{D\left(s^{\gamma}\right)}
$$

The transfer function (7) is quotient of quasi-polynomials $L\left(s^{\gamma}\right)$ and $D\left(s^{\gamma}\right)$. This makes easier the stability analysis. The transfer function (6) can be modeled at MATLAB platform only using its integer order, finite dimensional approximation. These approximations, both time-continuous and time-discrete are known. In this paper the Oustaloup Recursive Approximation (ORA) is applied. It is presented in the next subsection.

\subsection{The Oustaloup Recursive Approximation}

The method proposed by [9] allows to approximate an elementary FO transfer function $s^{\alpha}$ by the finite, integer-order transfer function, close to Pade approximation:

$$
s^{\alpha} \approx k_{f} \prod_{n=1}^{N} \frac{1+\frac{s}{\mu_{n}}}{1+\frac{s}{v_{n}}}=\frac{L_{O R A}(s)}{D_{O R A}(s)} .
$$

In (8) $N$ is the order of the approximation, $k_{f}$ is the steady state gain, $\mu_{n}$ and $v_{n}$ are calculated as follows:

$$
\begin{array}{r}
\mu_{1}=\omega_{l} \sqrt{\eta} \\
v_{n}=\mu_{n} \gamma, \quad n=1, \ldots, N \\
\mu_{n+1}=v_{n} \eta, \quad n=1, \ldots, N-1
\end{array}
$$

where:

$$
\begin{gathered}
\gamma=\left(\frac{\omega_{h}}{\omega_{l}}\right)^{\frac{\alpha}{N}} \\
\eta=\left(\frac{\omega_{h}}{\omega_{l}}\right)^{\frac{1-\alpha}{N}}
\end{gathered}
$$

In (10) $\omega_{l}$ and $\omega_{h}$ describe the range of angular frequency, for which the approximation is expected to work properly. The steady state gain $k_{f}$ is set to assure the convergence the step response of the approximation to step response of the real plant in a steady state.

\subsection{Fractional Order PID controller}

Consider the closed loop control system shown in the figure 1 . It contains controller described by transfer function $G_{c}(s)$ and plant described by the transfer function $G(s)$. Denote the transfer function of the whole closed-loop control system by $G_{c l}(s)$. It equals to: $G_{c l}(s)=\frac{Y(s)}{R(s)}=\frac{G_{c}(s) G(s)}{1+G_{c}(s) G(s)}$. The FOPID controller is described by the following transfer function (see for example [3], page 278):

$$
G_{c}(s)=k_{p}+k_{i} s^{-}+k_{d} s,
$$

where $k_{p}, k_{i}$ and $k_{d}$ are coefficients describing the proportional, integral and derivative actions respectively, $\alpha, \beta \in \mathbb{R}$ denote fractional orders of integral and derivative actions respectively.

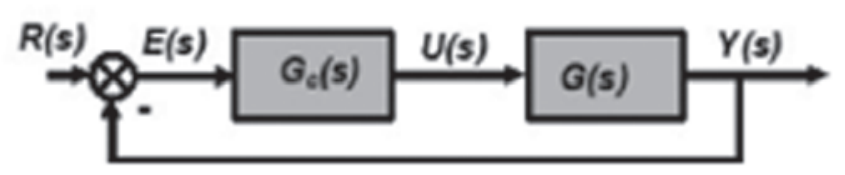

Fig. 1. Closed-loop control system

Rys. 1. Układ zamknięty z ujemnym sprzężeniem zwrotnym

\subsection{Stability of fractional order system}

The fundamental Bounded Input-Bounded Output (BIBO) stability condition for FO system described by the commesurate FO transfer function (7) is given by Matignon [6]. It is given also in [1 pages $21-22]$.

Theorem 1. (Matignon [6])

The fractional order system described by the transfer function (7) is stable if and only if:

$$
\left|\arg \left(\lambda_{n}\right)\right|>\frac{\gamma \pi}{2} \quad \forall n=1, \ldots, N,
$$

where $\lambda_{n}$ is the $n$-th root of polynomial $D\left(s^{\gamma}\right)$.

It is important to note that for $0.0<\lambda<1.0$ the stability area covers also the positive part of complex plane and for $\alpha=1.0$ the stability area is the same, as for integer order system. The condition (12) can be easily examined using numerical methods. This will be shown in the "Simulations" section.

\subsection{The control performance}

The control performance of the closed-loop control system can be tested using typical cost functions: settling time $T_{\mathrm{s}}$ and overshoot $y_{\max }$ expressed in \% of a reference value. As the 
integral cost function the Integral of Absolute Error (IAE) cost function will be used:

$$
\mathrm{IAE}=\int_{0}^{\infty}|e(t)| d t
$$

\section{The control plant and its model}

\subsection{The forced air heating system}

The considered forced heating system is required to assure the constant, relatively high temperature in the room with cubature about $75 \mathrm{~m}^{3}$. The system contains only heater. The cooler is not necessary due to environmental conditions and required range of preset temperatures. The simplified scheme of the system is illustrated by the SCADA screen shown in the figure 2 .

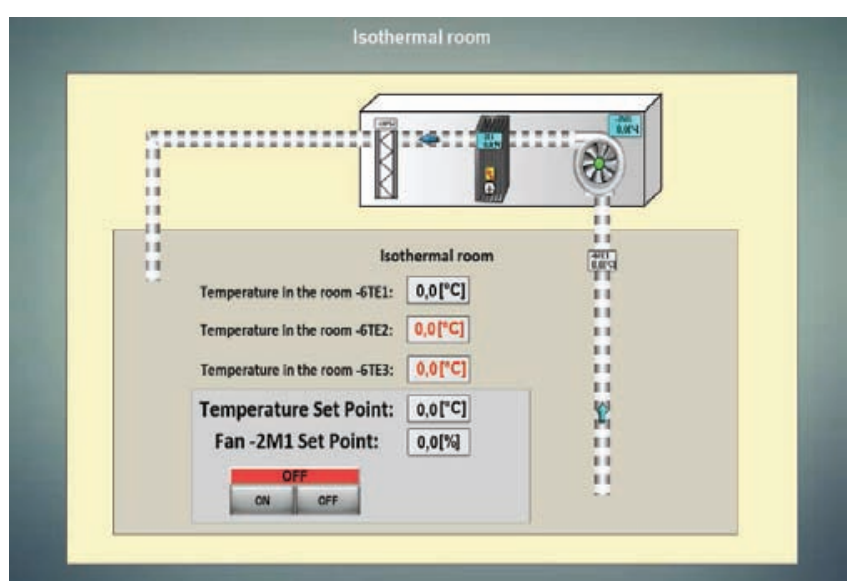

Fig. 2. The forced air heating system

Rys. 2. System ogrzewania powietrza

The cold air from the room is sucked via return duct to the heater and next, after being heated by the heater $2 \mathrm{E} 1$ and filtered by the HEPA filter, is supplied to the room via supply duct. The filter pollution is monitored by the pressure switch 11PS2. The electric heater $2 \mathrm{E} 1$ is protected from damage by monitoring air flow with the use of another pressure switch. The control signal is the power of the heater $2 \mathrm{E} 1$ expressed in the percent of its maximal range. The rotational speed of the blower $2 \mathrm{M} 1$ can be also applied as a control signal, but in this case, it is maximal and constant. The controlled temperature is measured inside the return duct by the sensor Pt 1000 (element 6 TE1 in the scheme). This location of the sensor allows
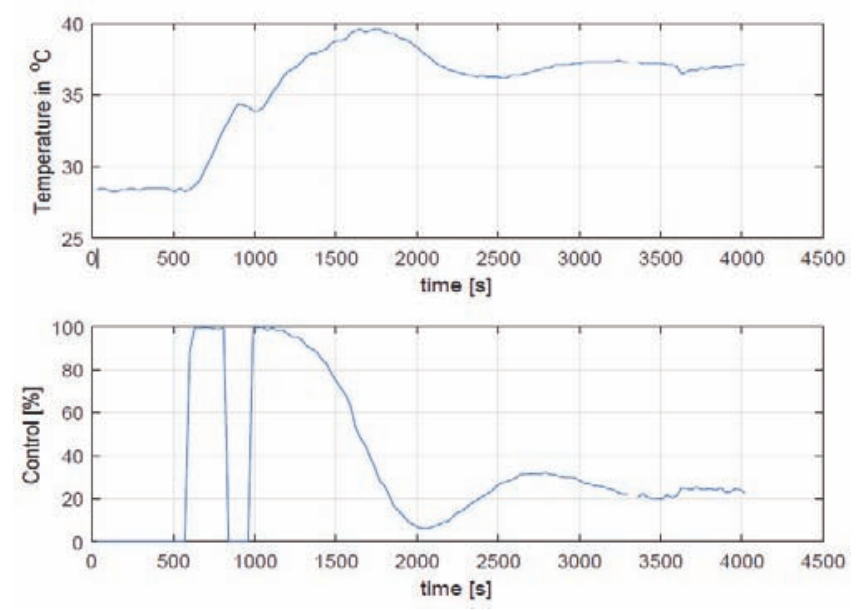

Fig. 3. The temperature measured by sensor 6TE1 and the power of heater $2 \mathrm{E} 1$

Rys. 3. Temperatura zmierzona przez czujnik 6TE1 i moc podgrzewacza $2 \mathrm{E} 1$ to avoid problems associated with the heterogeneous spatial temperature distribution in the room. Trends of temperature and control caused by the change of the preset temperature from $28{ }^{\circ} \mathrm{C}$ to $37{ }^{\circ} \mathrm{C}$ are shown in the figure 3 . These trends were measured during normal work of the heating system, controlled by classic PID controller. This "passive" method was only possible to apply in the considered case. The sample time during experiments was equal: $h=30 \mathrm{~s}$. The outside temperature is the biggest disturbance for the system. However, in case of such a short period of time it can be assumed as constant.

\subsection{Transfer function model of the temperature in the room}

The second order IO transfer function model of the temperature was obtained using the data shown in the figure 3 and tfest MATLAB function. It is as follows:

$$
G(s)=\frac{0.0002493 s+2.117 e^{-07}}{s^{2}+0.002379 s+5.053 e^{-07}}
$$

The fitting the response of model to response of the real plant is shown in the figure 4 .

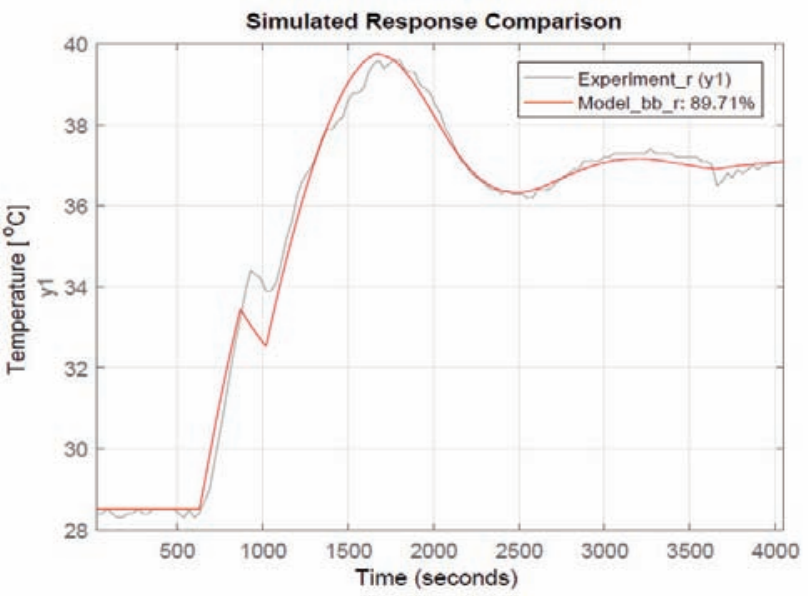

Fig. 4. The comparison the model (14) to real data

Rys. 4. Porównanie modelu (14) z danymi rzeczywistymi

\section{Stability analysis}

The general form of the transfer function of the plant with respect to (14) is expressed as follows:

$$
G(s)=\frac{b_{1} s+b_{0}}{s^{2}+a_{1} s+a_{0}} .
$$

If we recall the transfer function of the controller (11), then the open-loop transfer function $G_{o}(s)$ of the control system is as follows:

$G_{o}(s)=\frac{L(s)}{M(s)}=\frac{d_{5} s^{\alpha+\beta+1}+d_{4} s^{\alpha+1}+d_{3} s^{\alpha+\beta}+d_{2} s^{\alpha}+d_{1} s+d_{0}}{s^{\alpha+2}+a_{1} s^{\alpha+1}+a_{0} s^{\alpha}}$

where:

$$
\left\{\begin{array}{l}
d_{5}=b_{1} k_{d} \\
d_{4}=b_{1} k_{p} \\
d_{3}=b_{0} k_{d} \\
d_{2}=b_{o} k_{p} \\
d_{1}=b_{1} k_{i} \\
d_{0}=b_{o} k_{i}
\end{array}\right.
$$


The closed-loop transfer function of the control system is following:

$$
G_{c l}(s)=\frac{L(s)}{L(s)+M(s)}=\frac{L(s)}{D(s)},
$$

where $L(s)$ and $M(s)$ are given by $(16), D(s)$ is the characteristic polynomial of the closed-loop control system:

$$
\begin{aligned}
D(p)= & p^{11}+d_{5} p^{10}+\left(d_{4}+a_{1}\right) p^{7}+d_{3} p^{6}+ \\
& +\left(d_{2}+a_{0}\right) p^{3}+d_{1} p^{4}+d_{0}
\end{aligned}
$$

Next assume that orders of the both fractional order parts are equal: $\alpha=\beta=0.75$. It allows to substitute: $p=s^{0.25}$ and simplifies the further analysis. Additionally results of simulations show that this value of $\alpha$ and $\beta$ assures very good control performance.

Consequently the characteristic quasi-polynomial $D(p)=D\left(s^{0.25}\right)$ takes the following form:

$$
\begin{aligned}
D(p)= & p^{11}+d_{5} p^{10}+\left(d_{4}+a_{1}\right) p^{7}+d_{3} p^{6}+ \\
& +\left(d_{2}+a_{0}\right) p^{3}+d_{1} p^{4}+d_{0},
\end{aligned}
$$

where $\mathrm{d}_{5}-\mathrm{d}_{0}$ are given by (17). Consequently the stability condition (12) turns to the following form:

$$
\left|\arg \left(\lambda_{n}\right)\right|>\frac{\pi}{8} \quad \forall n=1, \ldots, 11,
$$

where $\lambda_{n}$ is the $n$-th root of the quasi polynomial (20). The roots of quasi polynomial (20) can be calculated numerically for given controller parameters $k_{p}, k_{i}$ and $k_{d}$. This will be shown in the next section.

\section{Simulations}

Simulations were executed with the use of transfer function model of plant (14) and controller (11). The fractional order parts of the controller were modeled using ORA approximation (8). The parameters of ORA approximation applied in experiments are given in the table 1 . The SIMULINK model

Table 1. The ORA approximation parameters

Tabela 1. Parametry aproksymacji ORA

\begin{tabular}{lll}
\hline $\mathbf{N}$ & $\omega_{1}$ & $\omega_{\mathrm{h}}$ \\
\hline 8 & $10^{-4}$ & $10^{4}$ \\
\hline
\end{tabular}
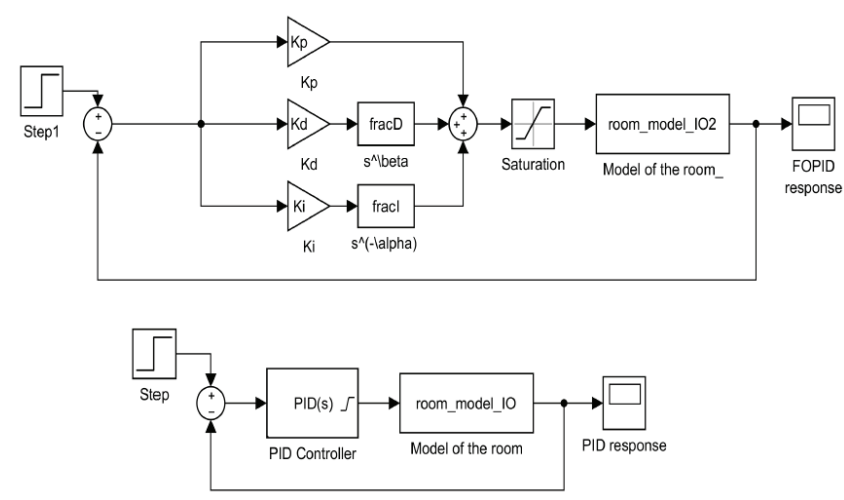

Fig. 5. The SIMULINK model applied to tests

Rys. 5. Modele simulinkowe zastosowane do testów

applied to tests is shown in the figure 5. The FOPID was tuned experimentally to obtain the shortest possible settling time with the smallest overshoot. In the table 1 it can be noted that the values of coefficients $k_{p}, k_{i}, k_{d}$ for the FOPID are much bigger, than suitable values for classic PID. This is caused by the fact that the steady-state gain of the ORA approximation applied to describe FO elements in the FOPID is very small. This causes that the work of the FO parts must be amplified by bigger values of coefficients.

The SIMULINK model contains also the control system with typical PID controller, tuned using the available auto-tune function. It is employed to compare the proposed results to typical, known solution.

The work of the system during change of preset temperature from $27^{\circ} \mathrm{C}$ to $37^{\circ} \mathrm{C}$ was tested. The level of the control signal in the both control systems was limited from $0 \%$ to $100 \%$. Parameters of the both controllers are collected in the table 2 . Results are illustrated by the figure 6 , the performance indices: settling time, overshoot and IAE (13) are given in the table 3 . The roots of characteristic quasi-polynomial for FOPID described in the table 2 are shown in figure 7.

Table 2. Parameters of controllers

Tabela 2. Parametry regulatorów

\begin{tabular}{cc}
\hline Controller & Parameters \\
\hline PID & $k_{p}=26.9920, k_{i}=0.0772, k_{d}=289.6436, N=0.9142$ \\
\hline FOPID & $k_{p}=500.0, k_{i}=0.1, k_{d}=200.0, \alpha=0.75, \beta=0.75$ \\
\hline
\end{tabular}

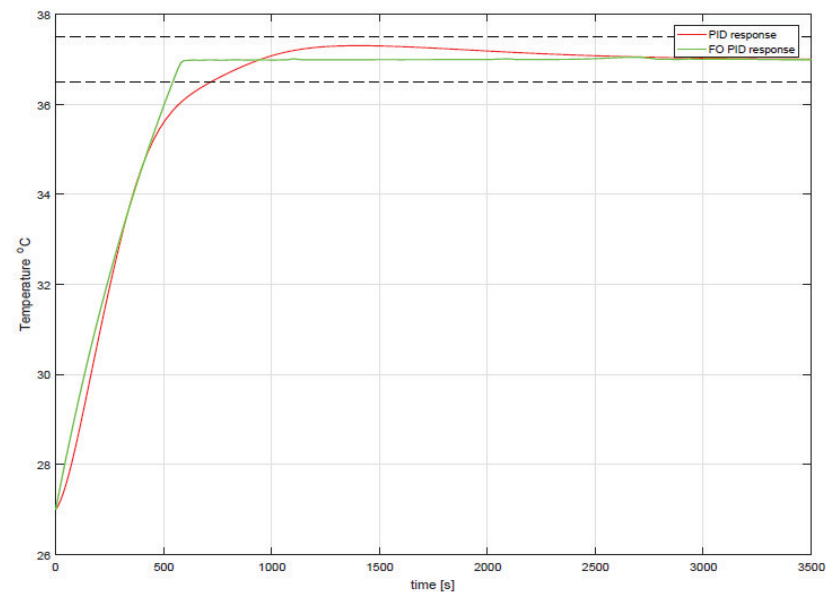

Fig. 6. PID vs FOPID controller step responses

Rys. 6. Porównanie odpowiedzi skokowych układu z regulatorem PID i regulatorem FOPID

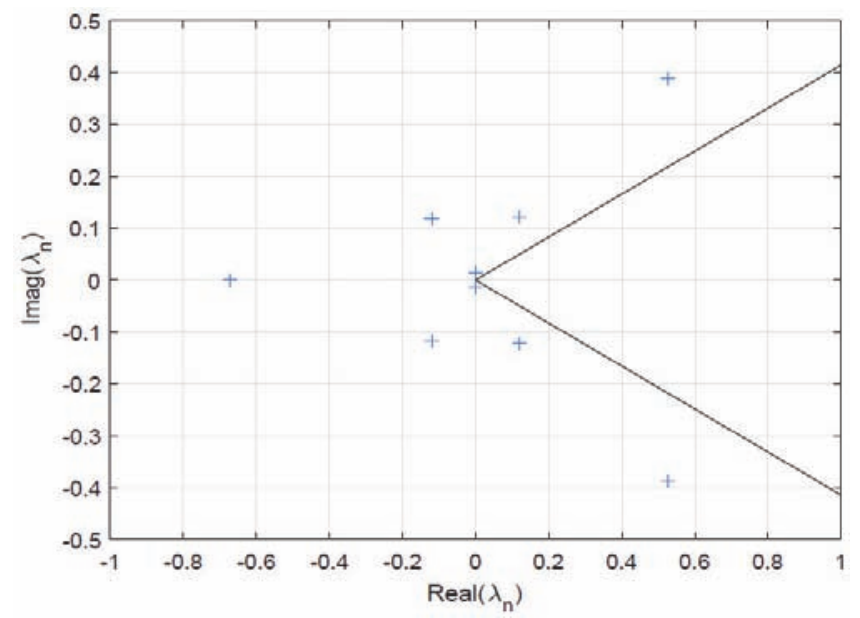

Fig. 7. The roots location for quasi polynomial (20) and parameters of FOPID from table 2 in the complex plane

Rys. 7. Lokalizacja na płaszczyźnie zespolonej pierwiastków quasi wielomianu (20) dla układu z regulatorem FOPID o parametrach zamieszczonych w tabeli 2 
Table 3. Performance indices for the both control systems

Tabela 3. Wskaźniki jakości regulacji dla obu systemów sterowania

\begin{tabular}{cccc}
\hline Controller & Settling time $[\mathrm{s}]$ & $\begin{array}{c}\text { Overshoot }[\% \text { of } \\
\text { preset value }]\end{array}$ & IAE (13) \\
\hline PID & 734.82 & 0.0 & $2.9304 \mathrm{e}+03$ \\
\hline FOPID & 540.37 & 3.05 & $2.8922 \mathrm{e}+03$ \\
\hline
\end{tabular}

\section{Final conclusions}

The main conclusion from the paper is that the proposed simple FOPID controller is able to assure the better control performance than typical PID controller tuned with the use of the auto-tune function. The FOPID controller is easy to tune using simple transfer function model of the plant and simulations.

The further investigations will cover a synthesis of robust FOPID controller for the considered plant. Another interesting problem is to give general stability conditions for the considered FOPID control system.

The practical verification at the real control system is recently impossible due to running production in the factory. Experiments will be run as soon as possible, probably during longer service break.

\section{References}

1. Caponetto R., Dongola G., Fortuna L., Petras I., Fractional order systems: Modeling and Control Applications. [in:] Chua L.O., editor, World Scientific Series on Nonlinear Science, 1-178. University of California, Berkeley, 2010.

2. Das S., Functional Fractional Calculus for System Identification and Control. Springer, Berlin 2010.

3. Faieghi M.R., Nemati A., On fractional-order PID design. [in:] Michalowski T., editor, Applications of MATLAB in Science and Engineering, 273-292. InTech, Rijeka Croatia, 2011.

4. Kaczorek T., Singular fractional linear systems and electrical circuits. "International Journal of Applied Mathematics and Computer Science", Vol. 21, No. 2, 2011, 379-384.

5. Kaczorek T., Rogowski K., Fractional Linear Systems and Electrical Circuits. Bialystok University of Technology, Bialystok, 2014.

6. Matignon D., Stability results for fractional differential equations with applications to control processing. [in:] IMACS-SMC Proceedings, Lille, France, July 1996, 963968.
7. Merrikh-Bayat F., Mirebrahimi N., Khalili M.R., Discrete-time fractional-order PID controller: Definition, tuning, digital realization and some applications. "International Journal of Control, Automation, and Systems", Vol. 13, No. 1, 2015, 81-90.

8. Edet E., Katebi R., On Fractional-Order PID Controllers, Fractional order systems: Modeling and Control Applications. [in:] Preprints of the 3rd IFAC Conference on Advances in Proportional-Integral-Derivative Control, Ghent, Belgium, May 9-11, 2018, 739-744.

9. Oustaloup A., Levron F., Mathieu B., Nanot F., Frequency-band complex noninteger differentiator: characterization and synthesis. IEEE Transactions on Circuits and Systems I: Fundamental Theory Applications, Vol. 47, No. 1, 2000, 25-39, DOI: $10.1109 / 81.817385$.

10. Petras I., Fractional - Order feedback control of a DC motor. "Journal of Electrical Engineering", Vol. 60, No. 3, 2009, 117-128.

11. Podlubny I., Fractional Differential Equations. Academic Press, San Diego 1999.

12. Ranganayakulu R., Babu G.U.B., Rao A.S., Patle D.S., A comparative study of fractional order $P I^{\wedge} / P I^{\wedge} D^{\mu}$ tuning rules for stable first order plus time delay processes. "Resource-Efficient Technologies", Vol. 2, No. 1, 2016, $136-152$.

13. Teplakov A., Fractional-order Modeling and Control of Dynamic Systems. PhD thesis, Tallin Unviersity of Technology, Estonia, Tallin 2015.

14. Valerio D., Costa J., Tuning rules for fractional PID controllers. [in:] Proceedings of the 2nd IFAC Workshop on Fractional Differentiation and its Applications Porto, Portugal, July 19-21, 2006, 1-6.

\author{
Streszczenie: Artykuł prezentuje implementację regulator PID ułamkowego rzędu (FOPID) do \\ sterowania temperaturą w pomieszczeniu izotermicznym stosowanym w fabryce farmaceutycznej. \\ Zaproponowano formułę regulatora dla modelu obiektu opisanego transmitancją oraz analizę \\ stabilności z wykorzystaniem Tw. Matignona. Wyniki badań symulacyjnych wskazują, że proponowany \\ regulator zapewnia lepszą jakość regulacji, niż typowy regulator PID dostrojony zużyciem auto- \\ tuningu.
}

Słowa kluczowe: ułamkowy regulator PID, system ogrzewania powietrza, stabilność, aproksymacja ORA 


\section{Krzysztof Oprzędkiewicz, PhD DSc}

kop@agh.edu.pl

He was born in Krakow in 1964. He obtained MSc in electronics in 1988, PhD and DSc in Automatics and Robotics in 1995 and 2009 at AGH University of Science and Technology (Krakow, Poland). He has been working at AGH University in Department of Automatics since 1988 , recently as a professor. In 20122016 he was a deputy dean of faculty of Electrotechnics, Automatics, Informatics and Biomedical Engineering at AGH University. His

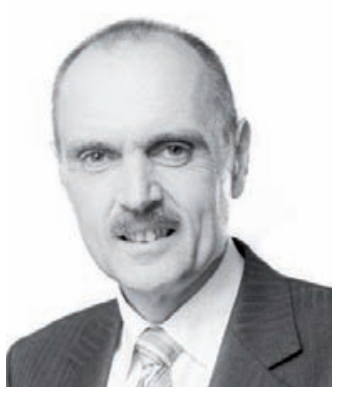

research covers infinite dimensional systems, fractional order modeling and control, uncertain parameter systems, industrial automation, PLC and SCADA systems, mobile robotics.

\section{Maciej Podsiadło, MSc BEng}

\author{
podsiadlomaciek5@gmail.com
}

He was born on 17.06.1994 in Cieszyn. The Master of Science degree as well as the Bachelor of Engineering degree were awarded to him with honours in June 2018 on the Faculty of Electrical Engineering, Automatics, Computer Science and Biomedical Engineering at the ACH University of Science and Technology. He is currently a PhD student in the Department of Automatics and Robotics. He works also as a integrator of the indu-

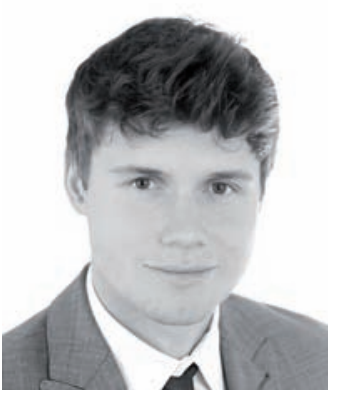
strial automation systems. His major scientific interest concerns with modeling of dynamic systems using fractional order calculus and fractional order control. 